\title{
Gamma-Linoleic Acid and Ascorbate Improves Skeletal Ossification in Offspring of Diabetic Rats
}

\author{
RATTANA BRADDOCK, C. MARTIN SIMÁN, KATHERINE HAMILTON, \\ HUGH O. GARLAND, $\uparrow$ AND COLIN P. SIBLEY
}

School of Biological Sciences, University of Manchester, Manchester M13 9PT, United Kingdom [R.B., H.O.G.]; Academic Unit of Child Health, University of Manchester, St. Mary's Hospital, Manchester M13 OJH, United Kingdom [C.M.S., K.H., C.P.S.]

\begin{abstract}
Maternal diabetes causes a range of complications in offspring, including reduced skeletal ossification. This study examined whether feeding $\gamma$-linoleic acid (GLA) and ascorbate, alone or in combination, to diabetic pregnant rats improves skeletal development in their offspring. In addition, $\mathrm{Ca}^{2+}$ concentration was monitored in maternal plasma and fetal tissue, as well as placental mRNA expression of calbindin- $\mathrm{D}_{9 \mathrm{k}}$. Female rats rendered diabetic with streptozotocin were fed GLA $(500 \mathrm{mg} / \mathrm{kg} / \mathrm{d})$, ascorbate $(290 \mathrm{mg} / \mathrm{kg} / \mathrm{d})$, ascorbyl-GLA (790 mg/kg/d), or GLA and ascorbate (500 and $290 \mathrm{mg} / \mathrm{kg} / \mathrm{d}$, respectively) throughout pregnancy. Fetal skeletons were studied after alizarin red staining. Fewer ossification centers were observed in offspring of diabetic rats compared with offspring of control rats $(68 \pm 4 \%$ of control, $p=0.01)$. An almost complete restoration of ossification occurred with all the treatments (92-95 $\pm 3 \%$ of control). The effects of treatment on fetal ossification could not be explained by altered maternal plasma $\mathrm{Ca}^{2+}$ concentrations or by mRNA
\end{abstract}

\section{ABSTRACT}

expression of the placental $\mathrm{Ca}^{2+}$-transporting protein calbindin$\mathrm{D}_{9 \mathrm{~K}}$. We conclude that GLA and/or ascorbate treatment was effective against diabetes-induced fetal ossification defects by a mechanism not related to placental $\mathrm{Ca}^{2+}$ supply. (Pediatr Res 51: 647-652, 2002)
ROS, reactive oxygen species
GLA, $\gamma$-linoleic acid
GTT, glucose tolerance test
STZ, streptozotocin
$\mathbf{C P}$, control pregnant
DP, diabetic pregnant
DG, diabetic pregnant with GLA
DA, diabetic pregnant with ascorbate
DASG, diabetic pregnant with ascorbyl-GLA
DGA, diabetic pregnant with GLA and ascorbate

Maternal diabetes during pregnancy is associated with an increased risk of several complications in the offspring, such as altered fetal growth, polyhydramnios, fetal loss, and congenital malformations (1-4). In addition, hypocalcemia and reduced bone mineral content are found in neonates of diabetic mothers (3, 5-7). However, some of the methodology used in earlier studies of neonatal bone mineral content has been questioned in a report that found no changes caused by maternal diabetes (8).

Several potential mechanisms have been proposed for the causes of diabetes-induced malformations, such as disturbances in the metabolism of inositol, prostaglandins, and ROS (9). Beneficial effects on embryonic development in diabetes have been reported subsequent to dietary supplementation with inositol, arachidonic acid, and antioxidants both in vitro and in vivo (10-14). A unifying etiology has been proposed, suggest-

Received June 18, 2001; accepted January 18, 2002.

Correspondence: Colin Sibley, Academic Unit of Child Health, University of Manchester, St. Mary's Hospital, Hathersage Road, Manchester, M13 0JH, U.K.; e-mail: colin.sibley@man.ac.uk

Supported by Scotia Pharmaceuticals and the government of Thailand.

†Deceased. ing that excess glucose causes increased leakage of ROS from the mitochondrion. The ROS will affect second messenger systems, including prostaglandins synthesized from arachidonic acid (9). Most of the experiments supporting this hypothesis have been performed in rats with neural tube defects as the main outcome measure.

Mechanistic data on bone mineralization defects in diabetes are less abundant than for embryonic dysmorphogenesis. Two fundamental mechanisms have been proposed to explain the ossification defects in offspring of diabetic rats, pinpointing either the $\mathrm{Ca}^{2+}$ supply or the bone maturation itself as being disturbed by diabetes. The "push" model suggests that supply of $\mathrm{Ca}^{2+}$ to the fetus is deficient, either through excessive $\mathrm{Ca}^{2+}$ loss in maternal urine (15) or reduced placental transport capacity (16). The "pull" model, on the other hand, suggests that the ossification process in the fetus itself is deficient, as indicated by reduced osteocalcin levels (17) and a reduced number of ossification centers, and thereby the fetus reduces its $\mathrm{Ca}^{2+}$ requirements. Recent evidence addressing this question supports the latter model (18). 
The aim of this study was to test whether GLA and ascorbate, which prevent other diabetes-induced malformations, have any effect on impaired bone mineralization in fetuses of diabetic rats. As a secondary end point, an attempt was made to elucidate the mechanism of action by studying $\mathrm{Ca}^{2+}$ concentrations in maternal plasma and fetal tissue, and placental mRNA expression of the $\mathrm{Ca}^{2+}$-transporting protein calbindin- $\mathrm{D}_{9 \mathrm{k}}$.

GLA is normally synthesized from linoleic acid, but the activity of the converting enzyme delta-6-desaturase is reduced in diabetes (19). GLA is an essential fatty acid and is metabolized to arachidonic acid and then further to second messengers including prostaglandins. Essential fatty acids have been found to have protective properties in experimental diabetes against nephropathy and neuropathy $(15,20-22)$ as well as embryonic neural tube defects.

Vitamin C (ascorbate) is an essential nutrient in humans, and one of its functions is as an antioxidant $(23,24)$. It is the primary antioxidant to be consumed in plasma exposed to oxidative stress $(25,26)$. Vitamin $\mathrm{C}$ is reduced in tissue and plasma in diabetes (27-29), and ascorbate fed to pregnant diabetic rats prevents the occurrence of fetal malformations and fetal loss (11).

In the current study, we fed rats made diabetic with STZ with GLA and ascorbate. These were administered separately, combined, and as the novel compound ascorbyl-GLA, where GLA and ascorbate have been linked together in equimolar concentrations. $\mathrm{Ca}^{2+}$ concentration and placental $\mathrm{Ca}^{2+}$ transport capacity were measured as well as fetal ossification. We demonstrated that all treatments improved mineralization of the fetal skeleton in diabetes.

\section{MATERIALS AND METHODS}

Female Sprague-Dawley rats were obtained at weaning (Charles River, Margate, Kent, U.K.) and were subsequently maintained under a constant 12-h photoperiod and a temperature of $20-22^{\circ} \mathrm{C}$ in standard cages and metabolism cages (for urinary data collection, as reported elsewhere). The rats had free access to food (Clarke's Rat and Mouse, Special Diet Services, Witham, Essex, U.K.) and deionized water, with or without supplements of GLA and/or ascorbate, throughout the experiment. Experimental groups and corresponding diets are outlined in Table 1. Food enriched with GLA was prepared by dropping GLA (Scotia Pharmaceuticals, Guildford, Surrey, U.K.) onto food pellets. Ascorbate (Sigma Chemical, Poole, Dorset, U.K.) and ascorbyl-GLA (Scotia Pharmaceuticals) were dissolved in deionized water. All doses were corrected to the food and water consumption of the previous day.

At 8 wk of age, rats were made diabetic with a single i.p. injection of $60 \mathrm{mg} / \mathrm{kg} \mathrm{STZ} \mathrm{(Sigma,} \mathrm{Poole,} \mathrm{Dorset,} \mathrm{UK)} \mathrm{dis-}$ solved in citric acid buffer ( $\mathrm{pH} 4.8$ ). Control animals were injected with buffer only. Only animals demonstrating polydipsia, polyuria, and glycosuria $(>5.5 \mathrm{mmol} / \mathrm{L})$ within $36 \mathrm{~h}$ of injection were included in the study. Blood glucose concentration was measured at the termination of the experiment in all pregnant rats with the glucose oxidase-peroxidase method (Ames Sera-Pak Reagent Kit, Bayer Diagnostics, Basingstoke, Hampshire, U.K.).

At 9 wk of age, the female rats were mated with control males of the same strain. The morning that a sperm plug was identified was designated d 0 of pregnancy. On d 21 of pregnancy, rats were killed by cervical dislocation and terminal blood was collected from the abdominal aorta into heparinized tubes. These were centrifuged immediately at $1000 \times g$ for 10 min to separate plasma. Fetuses and placentas were collected and weighed. In up to three fetuses per litter, amniotic fluid volume was measured by weighing the conceptus before and after rupturing the membranes. The amniotic fluid was collected for calcium and magnesium analysis. One fetus from each mother was selected at random for skeletal analysis and stored in $95 \%$ ethanol. The remaining fetuses were stored at $-20^{\circ} \mathrm{C}$ for calcium and magnesium measurements. Placentas were snap frozen in liquid nitrogen and stored at $-70^{\circ} \mathrm{C}$ for molecular analysis of calbindin- $\mathrm{D}_{9 \mathrm{~K}}$ (see below).

For $\mathrm{Ca}^{2+}$ and $\mathrm{Mg}^{2+}$ quantification, fetuses were dried at $75^{\circ} \mathrm{C}$ overnight and then ashed at $550^{\circ} \mathrm{C}$ for $16 \mathrm{~h}$. The ash was weighed and dissolved in $3 \mathrm{~mL} 3 \mathrm{M} \mathrm{HCl}$ and diluted 1:833 in $0.3 \%$ lanthanum solution or deionized water for $\mathrm{Ca}^{2+}$ and $\mathrm{Mg}$, respectively. Amniotic fluid and plasma were diluted 50 times in $0.3 \%$ lanthanum solution or deionized water. $\mathrm{Ca}^{2+}$ and $\mathrm{Mg}^{2+}$ concentration was then analyzed with an atomic absorption spectrophotometer (model 3100, PerkinElmer Instruments, Beaconsfield, Bucks, U.K.).

Ossification of fetal skeleton was examined after staining with alizarin red S (30). Fetuses were fixed in ethanol for more than $5 \mathrm{~d}$ and cleared from skin, viscera, and adipose tissue. They were then incubated in acetone overnight and subsequently macerated and stained in $1 \% \mathrm{KOH}$ and alizarin red $\mathrm{S}$ $(6 \mathrm{mg} / \mathrm{L})$ for $1.5 \mathrm{~d}$. After an overnight incubation in $70 \%$ ethanol/glycerol/benzyl alcohol (2:2:1), the fetuses were stored in glycerol until examination. With the aid of a stereomicroscope, ossification centers were counted in the vertebrae, ster-

Table 1. Experimental groups and their respective diet supplementation

\begin{tabular}{|c|c|c|c|}
\hline & Group & No. & Diet \\
\hline Control pregnant & $\mathrm{CP}$ & 7 & CRM, deionized water \\
\hline Diabetic pregnant & DP & 7 & CRM, deionized water \\
\hline Diabetic pregnant with GLA & DG & 8 & CRM with GLA $(500 \mathrm{mg} / \mathrm{kg} /$ day $)$, deionized water \\
\hline Diabetic pregnant with ascorbyl-GLA & DASG & 9 & $\begin{array}{l}\text { CRM, deionized water with ascorbyl-GLA ( } 790 \mathrm{mg} / \mathrm{kg} / \text { day) } \\
\text { (corresponding to } 500 \mathrm{mg} \text { GLA and } 290 \mathrm{mg} \text { ascorbate) }\end{array}$ \\
\hline Diabetic pregnant with GLA and ascorbate & DGA & 8 & $\begin{array}{l}\text { CRM with GLA }(500 \mathrm{mg} / \mathrm{kg} / \text { day }) \text {, deionized water with } \\
\text { ascorbate }(290 \mathrm{mg} / \mathrm{kg} / \mathrm{day})\end{array}$ \\
\hline
\end{tabular}


num, metacarpus, metatarsus, and the anterior and posterior phalanges.

Calbindin- $\mathrm{D}_{9 \mathrm{~K}}$ mRNA was measured as described previously (31) by extracting total RNA, according to Chomczinski and Sacchi (32), after thawing of placental tissue in guanidinium thiocyanate buffer. Three placentas were chosen at random from each litter for analyses. Extracted RNA was loaded on a nylon membrane (Hybond N, Amersham Pharmacia Biotech UK, Ltd., Little Chalfont, Buckinghamshire, U.K.) in dot blots $(20 \mu \mathrm{g})$ and hybridized with a ${ }^{32} \mathrm{P}$-labeled cDNA probe for rat intestinal calbindin- $\mathrm{D}_{9 \mathrm{~K}}$ (33). In previously reported Northern blot analyses of placental RNA, we have shown that this probe detects a single transcript of the correct size $(16,31)$. After radiographing, mRNA content was estimated densitometrically (Shimadzu, Kyoto, Japan) and normalized to oligodeoxythymidine hybridization on the same filter $(16,31)$.

A separate group of male rats was exposed to a GTT to test whether GLA or ascorbate affects the severity of diabetes. Male rats were chosen to avoid variability of plasma glucose caused by the female estrus cycle. These rats had an identical diet treatment protocol as the female rats described above. At 7 and 9 wk of age (1 wk before and after STZ injection, respectively) the rats were loaded with $2 \mathrm{~g} / \mathrm{kg}$ of glucose (i.p.) and tail vein blood glucose concentration was measured before and at 10, 30, 60, and $120 \mathrm{~min}$ after glucose loading. The area under the curve was then calculated. These rats were killed after the second GTT for collection of the pancreas into acid-alcohol (75\% ethanol: $\left.1.5 \% 12 \mathrm{M} \mathrm{HCl}: 23.5 \% \mathrm{H}_{2} \mathrm{O}\right)$. Insulin in the pancreas was determined with a rat insulin RIA kit (LINCO Research, St. Charles, MO, U.S.A.).

All data are given as means \pm SEM, with $n$ being the number of litters. Statistical comparisons were made with ANOVA and Dunnett's multiple comparison test, using GraphPad Prism software (version 3.00, GraphPad Software, San Diego, CA, U.S.A.). All significant differences indicated in tables are against the DP group.

\section{RESULTS}

GLA and ascorbate supplementation to the diet did not significantly alter the severity of the diabetic state of STZinjected male rats with respect to plasma glucose concentration (nontreated $30 \pm 4 \mathrm{mM}, n=6$; GLA $30 \pm 6 \mathrm{mM}, n=6$; ascorbate $19 \pm 5 \mathrm{mM}, n=5$ ), area under the curve (nontreated $4.8 \pm 0.5 \mathrm{~min} \cdot \mathrm{mol} / \mathrm{L}, n=6$; GLA $4.4 \pm 0.6 \mathrm{~min} \cdot \mathrm{mol} / \mathrm{L}, n=$
6; ascorbate $3.7 \pm 0.6 \mathrm{~min} \cdot \mathrm{mol} / \mathrm{L}, n=5$ ), or pancreatic insulin content (nontreated $3.3 \pm 0.5 \mathrm{nmol} / \mathrm{mg}, n=6$; GLA $2.0 \pm 0.8$ $\mathrm{nmol} / \mathrm{mg}, n=6$; ascorbate $4.1 \pm 1.0 \mathrm{nmol} / \mathrm{mg}, n=5$ ). With regard to maternal data, there was no significant difference in body weight between the groups over the course of pregnancy. Diet supplementation had no effect with respect to number of rats developing polyuria or polydipsia. Diet supplementation also had no effect on plasma glucose concentration with respect to the DP group (Table 2). The water consumption (except in the DG group) and urine production of diabetic rats was, however, significantly reduced with all treatments. Food consumption was not significantly affected by STZ injection or diet treatment (Table 2).

The litter size was not affected in the DP group as compared with CP or by any of the diet treatments as compared with DP (Table 3). Fetal weight was reduced and placental weight increased in diabetes but was not significantly affected with respect to the DP group by any of the diet supplementations (Table 3). The volume of amniotic fluid was overall increased by diabetes but was not further affected by diet treatment (Table 3).

The concentration of $\mathrm{Ca}^{2+}$ in maternal plasma was increased in diabetes and unaffected by treatment, apart from ascorbylGLA, which further increased plasma $\mathrm{Ca}^{2+}$ concentration (Table 4). Ultrafiltrable $\mathrm{Ca}^{2+}$ concentration was not significantly reduced by diabetes but was increased in the DG group. Concentration of $\mathrm{Ca}^{2+}$ in fetal ash was slightly reduced and $\mathrm{Ca}^{2+}$ content per fetus clearly reduced in the DP group compared with $\mathrm{CP} . \mathrm{Ca}^{2+}$ concentration in the GLA-supplemented groups (DG, DASG, DGA) was increased compared with DP (Table 4). The nominal increase of fetal $\mathrm{Ca}^{2+}$ content in treatment groups was not statistically significant. Amniotic fluid $\mathrm{Ca}^{2+}$ concentration was not different between groups (Table 4).

Maternal plasma $\mathrm{Mg}^{2+}$ concentration was not different between the CP and DP groups, but reduced in the DA group (Table 4). $\mathrm{Mg}^{2+}$ concentration in fetal ash and amniotic fluid was not different between the experimental groups, but $\mathrm{Mg}^{2+}$ content per fetus was reduced in the DP compared with the CP group (Table 4) and partially restored by the diet treatments, being significant in the DASG group only.

The fetal skeleton of the DP group, compared with the CP group, exhibited fewer ossification centers in sternum, caudal vertebrae, metatarsus and anterior and posterior phalanges. All treatments restored the number of ossification centers to close

Table 2. Maternal data

\begin{tabular}{|c|c|c|c|c|c|c|}
\hline & $\mathrm{CP}(n=7)$ & $\mathrm{DP}(n=7)$ & DG $(n=8)$ & DA $(n=8)$ & DASG $(n=9)$ & DGA $(n=8)$ \\
\hline Maternal terminal weight $(\mathrm{g})$ & $412 \pm 18$ & $371 \pm 11$ & $386 \pm 24$ & $374 \pm 11$ & $377 \pm 10$ & $356 \pm 11$ \\
\hline Maternal weight gain $(\mathrm{g})$ & $197 \pm 12$ & $156 \pm 11$ & $143 \pm 14$ & $140 \pm 7$ & $141 \pm 11$ & $128 \pm 12$ \\
\hline Maternal food consumption d $21(\mathrm{~g})$ & $40 \pm 12$ & $54 \pm 5$ & $53 \pm 2$ & $57 \pm 3$ & $53 \pm 4$ & $51 \pm 4$ \\
\hline Maternal urine production d $21(\mathrm{~mL})$ & $24 \pm 4^{* *}$ & $316 \pm 22$ & $224 \pm 21 * *$ & $222 \pm 14 * *$ & $162 \pm 17^{* *}$ & $228 \pm 14^{* *}$ \\
\hline $\begin{array}{l}\text { Maternal terminal blood glucose } \\
\text { concentration }(\mathrm{mmol} / \mathrm{L})\end{array}$ & $6.4 \pm 0.6$ & $40 \pm 1$ & $35 \pm 4$ & $39 \pm 2$ & $39 \pm 3$ & $44 \pm 2$ \\
\hline
\end{tabular}

Data presented as means \pm SEM. Group abbreviations are given in Table 1. Statistical analysis with ANOVA. Only significant differences versus the DP group are indicated.

$* p<0.05, * * p<0.01$. 
Table 3. Litter data

\begin{tabular}{|c|c|c|c|c|c|c|}
\hline & $\mathrm{CP}(n=7)$ & $\mathrm{DP}(n=7)$ & DG $(n=8)$ & DA $(n=8)$ & DASG $(n=9)$ & $\begin{array}{c}\text { DGA } \\
(n=8)\end{array}$ \\
\hline Litter size & $15.3 \pm 0.9$ & $13.0 \pm 0.8$ & $14.3 \pm 1.5$ & $14.3 \pm 0.8$ & $14.2 \pm 0.8$ & $13.1 \pm 0.8$ \\
\hline Fetal wet weight (g) & $5.4 \pm 0.1 * *$ & $4.1 \pm 0.3$ & $4.2 \pm 0.2$ & $4.4 \pm 0.2$ & $4.4 \pm 0.1$ & $4.2 \pm 0.2$ \\
\hline Amniotic fluid per fetus (mL) & $0.82 \pm 0.06^{*}$ & $1.00 \pm 0.05$ & $1.01 \pm 0.05$ & $1.12 \pm 0.05$ & $1.06 \pm 0.06$ & $1.09 \pm 0.05$ \\
\hline
\end{tabular}

Data presented as means \pm SEM. Group abbreviations are given in Table 1. Statistical analysis with ANOVA. Only significant differences versus the DP group are indicated.

$* * p<0.01$

Table 4. Maternal and fetal $\mathrm{Ca}^{2+}$ and $\mathrm{Mg}^{2+}$ data

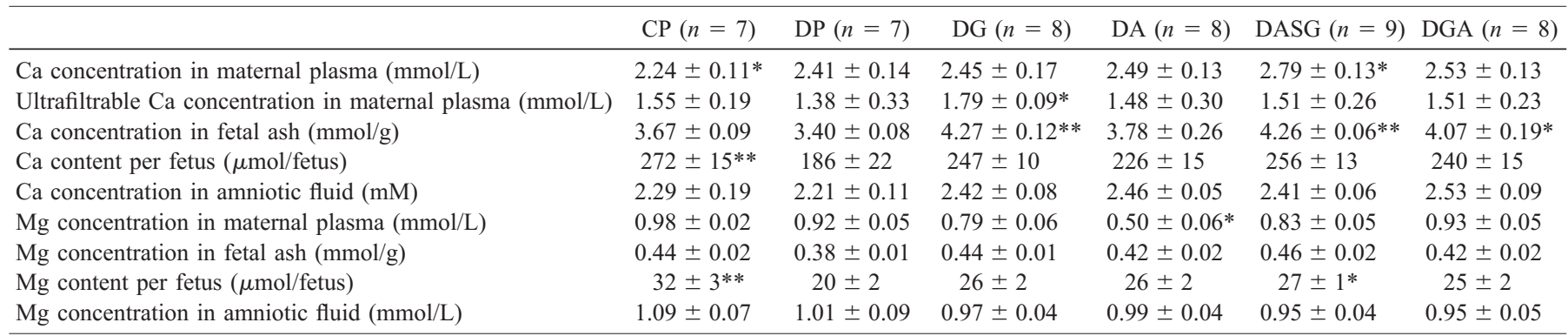

Data presented as means \pm SEM. Group abbreviations are given in Table 1. Statistical analysis with ANOVA. Only significant differences versus the DP group are indicated.

$* p<0.05, * * p<0.01$.

to normal in all but the metatarsus, where only the DG group was affected. Metacarpus was not affected by diabetes nor any of the treatments (Table 5).

The amount of calbindin- $\mathrm{D}_{9 \mathrm{~K}}$ mRNA in the placenta was reduced in all diabetic groups compared with the CP group. Treatment did not affect the calbindin- $\mathrm{D}_{9 \mathrm{~K}}$ mRNA expression (Fig. 1).

\section{DISCUSSION}

This study shows that both GLA and ascorbate have the potential to normalize defective skeletal development in offspring of diabetic rats, as indicated by normalization of the number of ossification centers and calcium concentration in fetal carcasses. However, no synergistic effects of the treatments were noted when administered together, with the doses used in this study.

Treatment with GLA and ascorbate started before induction of diabetes. As STZ acts via free oxygen radicals, and both GLA and ascorbate have antioxidative properties, there is a possibility that the treatment may have reduced the severity of

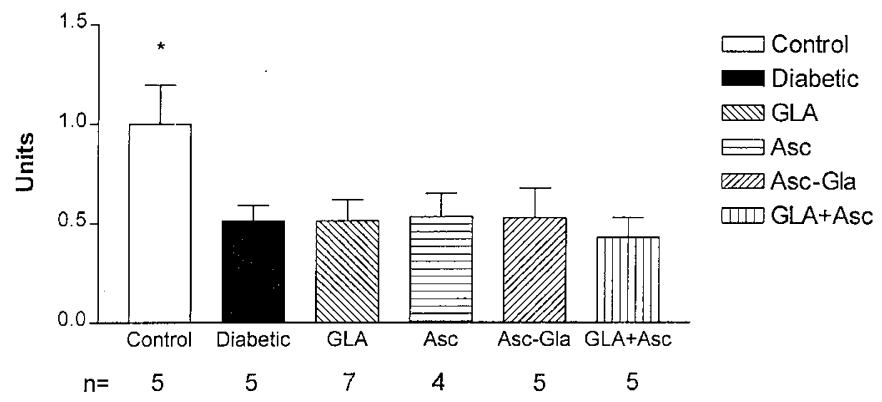

Figure 1. Calbindin- $D_{9 K}$ mRNA expression in d-21 placentas. Calbindin- $D_{9 K}$ mRNA signal on dot blots is given as a ratio oligodeoxythymidine and is normalized to the average of the $\mathrm{CP}$ group. Data presented as mean $\pm \mathrm{SEM}$, number as shown. $A s c$, ascorbyl; other group abbreviations are given in Table 1. Statistical analysis with ANOVA. Only significant differences $v s$ the DP group are indicated. $* p<0.05$.

the diabetic state. In a study with evening primrose oil (rich in GLA), a reduction in blood glucose concentration was noted (15). The effect of another diabetogenic drug acting via free

Table 5. Fetal skeletal ossification

\begin{tabular}{|c|c|c|c|c|c|c|}
\hline & $\mathrm{CP}(n=7)$ & DP $(n=7)$ & DG $(n=8)$ & $\mathrm{DA}(n=8)$ & $\operatorname{DASG}(n=9)$ & $\begin{array}{c}\text { DGA } \\
(n=8)\end{array}$ \\
\hline Sternum & $6.0 \pm 0 * *$ & $3.9 \pm 0.8$ & $5.9 \pm 0.1 * *$ & $6.0 \pm 0 * *$ & $5.9 \pm 0.1^{* *}$ & $5.6 \pm 0.2 * *$ \\
\hline Metacarpus & $4.0 \pm 0$ & $3.7 \pm 0.2$ & $4.0 \pm 0$ & $4.0 \pm 0$ & $4.0 \pm 0$ & $4.0 \pm 0$ \\
\hline Metatarsus & $4.9 \pm 0.1 * *$ & $4.1 \pm 0.1$ & $4.8 \pm 0.1^{*}$ & $4.3 \pm 0.2$ & $4.3 \pm 0.1$ & $4.0 \pm 0.0$ \\
\hline Posterior phalanx & $4.9 \pm 0.1 * *$ & $2.9 \pm 0.1$ & $4.7 \pm 0.2 * *$ & $5.0 \pm 0 * *$ & $5.0 \pm 0 * *$ & $5.0 \pm 0^{* *}$ \\
\hline Caudal vertebrae & $5.3 \pm 0.2 * *$ & $2.1 \pm 0.3$ & $4.4 \pm 0.3^{* *}$ & $3.8 \pm 0.3^{* *}$ & $4.2 \pm 0.1^{* *}$ & $4.4 \pm 0.3 * *$ \\
\hline
\end{tabular}

Data presented as means \pm SEM of the number of ossification centers identified. Group abbreviations are given in Table 1. Statistical analysis with ANOVA. Only significant differences versus the DP group are indicated.

$* p<0.05, * * p<0.01$. 
oxygen radicals, alloxan (34), can be blocked by antioxidants (35). We therefore performed a GTT with a separate group of animals. No significant effect of the diet treatment was noted, nor any effect on blood glucose concentration in pregnant rats at the end of the experiment. There may be a trend, although not statistically significant, of fewer animals becoming diabetic after diet treatment. However, when stratifying for diabetes, as done with the female rats in this study, there are no signs of the treatment affecting the severity of diabetes. Thus, in this study, the improvement of fetal outcome by the treatment was by a mechanism not related to an effect on the diabetic state itself.

Although the total $\mathrm{Ca}^{2+}$ concentration in maternal plasma was increased in diabetic dams, the ultrafiltrable fraction, which is accessible for placental transfer, was not significantly affected by diabetes. There were nominal increases in maternal ultrafiltrable $\mathrm{Ca}^{2+}$ with all treatments, but this was only statistically significant with GLA.

We have previously reported that placental calbindin- $\mathrm{D}_{9 \mathrm{~K}}$ mRNA expression is closely related to the maternofetal $\mathrm{Ca}^{2+}$ flux in the rat $(16,31)$. Here, $\mathrm{Ca}^{2+}$ calbindin- $\mathrm{D}_{9 \mathrm{~K}}$ mRNA expression was significantly reduced in placentas of diabetic rats, as reported previously (16). However, diet treatment did not affect placental calbindin- $\mathrm{D}_{9 \mathrm{~K}}$ expression, thereby not supporting a role of $\mathrm{Ca}^{2+}$ transfer in the etiology of the treatment effects on fetal bone formation. Furthermore, if calbindin- $\mathrm{D}_{9 \mathrm{~K}}$ is expressed as mRNA concentration per placental/fetal weight ratio, there is no difference between normal and diabetic groups (data not shown). If it is assumed that calbindin- $\mathrm{D}_{9 \mathrm{~K}} / \mathrm{actin}$ represents $\mathrm{Ca}^{2+}$ transport capacity, and that placental and fetal weight is a proxy for transport area and fetal $\mathrm{Ca}^{2+}$ requirements, respectively, the data then suggest that there is appropriate $\mathrm{Ca}^{2+}$ supply to the fetus in all groups. Thus, the current data do not support the involvement of placental calbindin- $\mathrm{D}_{9 \mathrm{~K}}$ mRNA expression in the reduced fetal ossification in diabetes, supporting the "pull" model for reduced fetal ossification caused by maternal diabetes in rats. This is further corroborated by observations in spontaneously diabetic BB rats, suggesting the fetal hypomineralization is caused by delayed bone maturation (18). Hence, the effect of GLA and ascorbate on ossification of the fetus in this study is to be sought in the fetal bone development.

The underlying mechanism of abnormal embryo development in diabetes has been ascribed to damage caused by ROS, which disturbs prostaglandin metabolism (9). The antioxidants ascorbate, $\alpha$-tocopherol, and butylated hydroxytoluene prevent micrognathia and fetal resorptions, as studied in experimental diabetic pregnancy (11-13). Similarly, arachidonic acid reduces the incidence of neural tube defects in embryos of diabetic rats $(10,36)$, suggesting an effect of membrane stabilization after ROS damage. These mechanistic studies, however, relate to morphologic end points that may be unrelated to skeletal ossification. Micrognathia, for example, was recently demonstrated to be caused by "normal" bone formation around a malformed Meckel's cartilage (37). Nevertheless, the current report showing clearcut beneficial effects of GLA and ascorbate treatments provides evidence that skeletal ossification abnormalities in diabetes are caused by ROS.
The mechanism by which ROS affects bone ossification remains unknown. Speculatively, there could either be a direct effect on osteoblast/osteoclast activity or a secondary effect via regulatory factors affecting ossification. One possibility is that diabetes-induced malformation of the fetal parathyroid gland (37) causes reduced fetal production of PTH, which would affect bone formation. Reduced PTH concentrations have been reported in umbilical blood in children of diabetic mothers (5).

It is interesting to note that the ossification of metacarpus and metatarsus was relatively little affected by diabetes and the diet treatments. This may provide a useful tool for mechanistic dissections in future experiments.

In conclusion, we have demonstrated that GLA and ascorbate can restore skeletal ossification in offspring of diabetic rats. The mechanism by which the treatment works is unrelated to $\mathrm{Ca}^{2+}$ supply to the fetus. Rather, the treatment is likely to be related to amelioration of diabetes-induced ROS effects on skeletal ossification in the offspring.

Acknowledgments. The authors thank Ms. Catherine Davidge and Dr. Jo Glazier for advice and assistance. This paper is dedicated to the memory of our friend and colleague Dr. Hugh O. Garland.

\section{REFERENCES}

1. Mølsted-Pedersen L, Tygstrups I, Pedersen J 1964 Congenital malformations in new-born infants of diabetic woman: correlation with maternal diabetic vascular complications. Lancet i:1124-1126

2. Garner P 1995 Type I diabetes mellitus and pregnancy. Lancet 346:157-161

3. Tsang RC, Kleinman LI, Sutherland JM, Light IJ 1972 Hypocalcemia in infants of diabetic mothers. J Pediatr 80:384-395

4. Dermarini S, Mimouni F, Tsang RC, Khoury J, Hertzberg V 1994 Impact of metabolic control of diabetes on neonatal hypocalcemia: a randomized study. Obstet Gynecol 83:918-922

5. Cruikshank DP, Pitkin RM, Varner MW, Williams GA, Hargis GK 1983 Calcium metabolism in diabetic mother, fetus, and newborn infant. Am J Obstet Gynecol 145:1010-1016

6. Mimouni F, Steichen JJ, Tsang RC, Hertzberg V, Miodovnik M 1988 Decreased bone mineral content in infants of diabetic mothers. Am J Perinatol 5:339-343

7. Verrotti A, Chiarelli F, Capani F, Morgese G 1992 Calcium metabolism in type 1 diabetes mellitus. Diabetes Nutr Metab 5:231-236

8. Lapillonne A, Guerin S, Braillon P, Claris O, Delmas PD, Salle BL 1997 Diabetes during pregnancy does not alter whole body bone mineral content in infants. J Clin Endocrinol Metab 82:3993-3997

9. Eriksson UJ, Borg LAH, Cederberg J, Nordstrand H, Siman CM, Wentzel C, Wentzel P 2000 Pathogenesis of diabetes-induced congenital malformations. Ups J Med Sci $105: 2$

10. Reece EA, Wu YK, Wiznitzer A, Homko C, Yao J, Borenstein M, Sloskey G 1996 Dietary polyunsaturated fatty acid prevents malformations in offspring of diabetic rats. Am J Obstet Gynecol 175:818-823

11. Simán CM, Eriksson UJ 1997 Vitamin C supplementation of the maternal diet reduces the rate of malformation in the offspring of diabetic rats. Diabetologia 40:1416-1424

12. Simán CM, Eriksson UJ 1997 Vitamin E decreases the occurrence of malformations in the offspring of diabetic rats. Diabetes 46:1054-1061

13. Eriksson UJ, Simán CM 1996 Pregnant diabetic rats fed the antioxidant butylated hydroxytoluene show decreased occurrence of malformations in offspring. Diabetes 45:1497-1502

14. Reece EA, Khandelwal M, Wu YK, Borenstein M 1997 Dietary intake of myoinositol and neural tube defects in offspring of diabetic rats. Am J Obstet Gynecol $176: 536-539$

15. Garland HO, Forshaw AG, Sibley CP 1997 Dietary essential fatty acid supplementation, urinary calcium excretion and reproductive performance in the diabetic pregnant rat. J Endocrinol 153:357-363

16. Husain SM, Birdsey TJ, Glazier JD, Mughal MZ, Garland HO, Sibley CP 1994 Effect of diabetes mellitus on maternofetal flux of calcium and magnesium and calbindin ${ }_{9 \mathrm{k}}$ mRNA expression in rat placenta. Pediatr Res 35:376-381

17. Verhaeghe J, Van Herck E, Bouillon R 1995 Umbilical cord osteocalcin in normal pregnancies and pregnancies complicated by fetal growth retardation or diabetes mellitus. Biol Neonate 68:377-383

18. Verhaeghe J, van Bree R, van Herck E, Rummens K, Vercruysse L, Bouillon R, Pijnenborg R 1999 Pathogenesis of fetal hypomineralization in diabetic rats: evidence for delayed bone maturation. Pediatr Res 45:209-217 
19. Horrobin DF, Carmichael HA 1992 Essential fatty acids in relation to diabetes. In: Horrobin DF (ed) Treatment of Diabetic Neuropathy: A New Approach. Churchill Livingstone, Edinburgh, pp 21-39

20. Barcelli UO, Weiss M, Beach D, Motz A, Thompson B 1990 High linoleic acid diets ameliorate diabetic nephropathy in rats. Am J Kidney Dis 16:244-251

21. Hounsom L, Horrobin DF, Tritschler H, Corder R, Tomlinson DR 1998 A lipoic acid-gamma linoleic acid conjugate is effective against multiple indices of experimental diabetic neuropathy. Diabetologia 41:839-843

22. Tulloch I, Smellie WS, Buck AC 1994 Evening primrose oil reduces urinary calcium excretion in both normal and hypertensive rats. Urol Res 22:227-230

23. Bendich A, Machlin LJ, Scandurra O, Burton GW, Wayner DDM 1986 The antioxidant role of vitamin C. Adv Free Radic Biol Med 2:149-444

24. Niki E 1991 Vitamin C as an antioxidant. World Rev Nutr Diet 64:1-30

25. Frei B, England L, Ames BN 1989 Ascorbate is an outstanding antioxidant in human blood plasma. Proc Natl Acad Sci U S A 86:6377-6381

26. Frei B, Stocker R, England L, Ames BN 1990 Ascorbate: the most effective antioxidant in human blood plasma. Adv Exp Med Biol 264:155-163

27. Som S, Basu S, Mukherjee D, Deb S, Choudhury PR, Mukherjee S, Chatterjee SN, Chatterjee IB 1981 Ascorbic acid metabolism in diabetes mellitus. Metabolism 30:572-577

28. Yew MS 1983 Effect of streptozotocin diabetes on tissue ascorbic acid and dehydroascorbic acid. Horm Metab Res 15:158

29. McLennan S, D.K. Y, Fisher E, Capogreco C, Heffernan S, Ross GR, Turtle JR 1988
Deficiency of ascorbic acid in experimental diabetes. Relationship with collagen and polyol pathway abnormalities. Diabetes 37:359-361

30. Staples RE, Schnell VL 1964 Refinements in rapid clearing technique in the $\mathrm{KOH}$ alizarin red S method for fetal bone. Stain Technol 39:31-63

31. Glazier JD, Atkinson DE, Thornburg KL, Sharpe PT, Edwards D, Boyd RDH, Sibley CP 1992 Gestational changes in $\mathrm{Ca}^{2+}$ transport across rat placenta and mRNA for calbindin 9k and $\mathrm{Ca}^{2+}$-ATPase. Am J Physiol 263:R930-R935

32. Chomczinski P, Sacchi N 1987 Single step method of RNA isolation by acid guanidinium thiocyanate-phenol-chloroform extraction. Anal Biochem 162:156-159

33. Desplan C, Thomasset M, Moukhtar M 1983 Synthesis, molecular cloning and restriction analysis of DNA complementary to vitamin D-dependent calcium binding protein mRNA from rat duodenum. J Biol Chem 258:2762-2765

34. Lenzen S, Munday R 1991 Thiol group reactivity, hydrophilicity and stability of alloxan, its reduction products and its $N$-methyl derivates and a comparison with ninhydrin. Biochem Pharmacol 42:1385-1391

35. Soto CP, Perez BL, Favari LP, Reyes JL 1998 Prevention of alloxan-induced diabetes in the rat by silymarin. Comp Biochem Physiol C Pharmacol Toxicol Endocrinol 119:125-129

36. Goldman AS, Baker L, Piddington R, Marx B, Herold R, Egler J 1985 Hyperglycemia-induced teratogenesis is mediated by a functional deficiency of arachidonic acid. Proc Natl Acad Sci U S A 82:8227-8231

37. Simán CM, Gittenberger-de Groot AC, Wisse B, Eriksson UJ 2000 Neural crest related malformations in offspring of diabetic rats decreases with vitamin $\mathrm{E}$ treatment. Teratology 61:355-367 